prav-ta-povnovazhen-u-sferi-derzhavnoyi-reyestratsiyi/ (дата звернення 07.10.2020).

2. Навчальний посібник з надання адміністративних послуг для адміністраторів центрів Дії (центри надання адміністративних послуг): Посібник / Андрєєв О.В., Гугля О.С., Маценко М.М., Ткач Н.О., Шамрай Н.В. Київ, 2020. 263 с.

3. Порядок проведення державної реєстрації прав. Тренінг для персоналу ЦНАП. Державна реєстрація речових прав на нерухоме майно та їх обтяжень. URL: https:/tsnap.ulead.org.ua/staff-training/ page/2/ (дата звернення 07.10.2020).

4. Кодекс України про адміністративні правопорушення: Закон України від 07.12.1984 № 8073-Х. Відомості Верховної Ради УРСР. 1984. № 51. Ст. 1122.

5. Про державну реєстрацію речових прав на нерухоме майно та їх обтяжень: Закон України від 01.07.2004 № 1952-IV. Відомості Верховної Ради Украӥни. 2004. № 51. Ст. 553.

DOI https://doi.org/10.30525/978-9934-26-040-7-47

\title{
ВПЛИВ ІНФОРМАЦІЙНИХ ТЕХНОЛОГІЙ НА ФОРМУВАННЯ ПРОФЕСІЙНИХ НАВИКІВ МАЙБУТНЬОГО ЮРИСТА
}

\author{
Уткіна Г. А. \\ кандидат економічних наук,
}

доиент кафедри спеиіальних дисичилін та професійної підготовки

Донецького юридичного інституту

Міністерства внутрішніх справ України

м. Кривий Ріг, Дніпропетровська область, Україна

Доцюк Т. К.

кандидат історичних наук,

доиент кафедри загально-правових дисииплін

Донеиького юридичного інституту

Міністерства внутрішніх справ України

м. Кривий Ріг, Дніпропетровська область, Україна

Динамічність

на формування суспільних

культури трансформацій комплексно мови, традицій, історичної впливає пам'яті, 
національних цінностей суб'єктів матеріального й духовного виробництва. При розбудові правової держави, громадянського суспільства необхідно зосередити зусилля на формуванні правової культури як вияву особливостей менталітету нації, підвищенні професійної компетентності майбутніх спеціалістів у сфері права, що обов'язково передбачає поглиблене вивчення інформаційних технологій, які сприяють розвитку освіченої, гармонійно розвиненої особистості. Безумовно, дослідження проблем новітніх підходів до використання інформаційних технологій у сучасному юридичному просторі є вкрай важливим, оскільки формування культури юристів без покращення інформаційних знань та підвищення рівня знань у сфері інформаційних технологій є неможливою.

3 моменту набуття Україною незалежності наша країна йде шляхом побудови демократичної, соціальної, правової держави. При цьому спостерігається активне реформування усіх сфер життя суспільства, в тому числі й правової. Так, перед сучасною правовою освітою стоїть вимога переглянути традиційні уявлення про розвиток особистості студента. Крім того, постало завдання максимального розкриття i розвитку потенціалу кожної особистості, формування людини як суб'єкта соціального та професійного життя, підготовки іiі до самовдосконалення, самовизначення та самореалізації.

Інтенсивне зближення інтересів права й інформатики є об'єктивним i закономірним процесом, викликаним нагальною необхідністю у взаємному використанні новітніх досягнень цих наук, який має два взаємозв'язані аспекти: прикладний і змістовий. Тобто використання останніх досягнень у галузі інформаційних технологій, пристосованих або спеціально розроблених для розвитку й функціонування юридичної науки і практики, з одного боку, і юридичне закріплення питань, пов'язаних з упровадженням у певну сферу суспільних відносин цих інформаційних технологій, -3 другого $[1$, с. 5$]$.

3 розвитком інформаційного суспільства збільшуються потоки інформації, швидкість іï обробки й розповсюдження, і у зв'язку 3 цим виникає потреба в захисті інтересів суб'єктів, які використовують інформацію у своїй діяльності. Тому важливо знайти такі правові механізми, які забезпечать правове регулювання інформаційних відносин, що дозволить економічно ефективно розвивати галузь людської діяльності виробництва й використання інформації цю, а також протистояти різним правопорушенням, пов'язаним з нею [2, с. 7].

Правову інформатизацію слід розглядати як процес цілеспрямованого формування, перетворення та застосування інформаційних ресурсів засобами інформаційних систем і інформаційних технологій 186 
для вирішення задач юриспруденції, надання інформаційним ресурсам нових якісних і кількісних характеристик, властивих правовим процесам, одержання інформаційної продукції, затребуваної в юридичній діяльності, і надання правових інформаційних послуг власниками правових інформаційних ресурсів користувачам інформаційних мереж i інформаційних технологій.

Сьогодні правова інформатизація являє собою одну з необхідних умов гармонічного розвитку суспільства та держави, удосконалення систем національного законодавства, особливо в сучасних умовах формування інформаційного суспільства. Неоціненне значення при цьому набуває освіта в галузі правової інформатизації як спосіб не тільки зміни свідомості, мислення майбутнього юриста, але й надання йому практичного використання можливостей, досягнутих комп'ютерними технологіями, тобто розвиток інформаційних технологій забезпечує юриста новими інструментами, сприяє змінам у діловій практиці [3, с. 118].

Отже, сучасні тенденції у розвитку освіти України, головний вектор яких спрямований на упровадження концептуальних ідей Болонського процесу, передбачають модернізацію традиційних [4, с. 88], а також застосування новітніх підходів до підготовки майбутніх професіоналів, зокрема й використання інноваційних методів навчання.

Нові обрії розвитку вищої освіти пов'язані з інноваційними технологіями, що сприяють створенню знань, управлінню ними, їхньому поширенню, доступу до них і контролю за їх засвоєнням. Результати інноваційного навчання, безумовно, орієнтують на розвиток особистості кожного студента, формування його готовності до реального життя та професійної діяльності, до розвитку творчого мислення, критичного аналізу навколишнього світу й себе в ньому тощо.

Впровадження й утвердження нового в освітній практиці зумовлене позитивними трансформаціями, а отже, має стати засобом вирішення актуальних завдань конкретного навчального закладу і витримати експериментальну перевірку для остаточного застосування інновацій. Передусім, це має полягати в сучасному моделюванні, організації нестандартних лекційно-практичних, семінарських занять; індивідуалізації засобів навчання; кабінетного, групового і додаткового навчання; факультативного, за вибором студентів, поглиблення знань; проблемно-орієнтованого навчання; науково-експериментального при вивченні нового матеріалу; розробці нової системи контролю оцінки знань; застосуванні комп'ютерних, мультимедійних технологій; навчальнометодичної продукції нового покоління [5, с. 28]. В процесі підготовки 
майбутнього професіонала важливим $є$ використання різноманітних технологій навчання, в тому числі й інноваційного змісту.

Виходячи 3 вищенаведеного, сучасна особистість формується в умовах пристосовування своїх внутрішніх цінностей до умов інноваційного середовища. Головним каналом цих процесів і виступає культуротворчість як «адаптивна стратегія» особистості $[6$, с. 13]. Реалізація іiі в усіх сферах діяльності на сучасному етапі знайшла втілення в інноваційній культурі, яка розглядається як опосередкована субстанція між оточуючим середовищем, яке базується на інноваційних засадах, та внутрішньою готовністю особистості до існування в цих умовах. Вона забезпечує сприйнятливість людей до нових ідей, їх готовність і здатність підтримувати й реалізовувати інновації в усіх сферах життя [7, с. 338]. Звідси інноваційна спрямованість формування культури особистості передбачає його залучення до діяльності зі створення, опанування й використання освітніх нововведень у практиці, пристосування до створеного в освітньому закладі інноваційного культурного середовища.

Таким чином, сучасна юридична діяльність нерозривно пов'язана 3 грамотною організацією інформаційних процесів, а також освоєнням i використанням сучасних інформаційно-комунікаційних технологій. Звідси в процесі підготовки майбутнього юриста важливим $є$ використання різноманітних технологій навчання, в тому числі й інноваційного змісту. Впровадження інформаційних технологій для роботи юристів $\epsilon$ ефективним засобом реформування правової освіти, підвищення ефективності навчання, підготовки не просто фахівця, а високопрофесійного фахівця в галузі права.

\section{Література:}

1. Заплотинський Б.А. Інформаційні технології в юридичній діяльності. Посібник. - Київський інститут інтелектуальної власності та права НУ «Одеська юридична академія», кафедра інформаційноаналітичної та інноваційної діяльності, 2018. - 108 с.

2. Правова інформація та комп'ютерні технології в юридичній діяльності: Навч. посіб. / В.Г. Іванов, С.М. Іванов, В.В. Карасюк та ін.; За заг. ред. В.Г. Іванова. - Х.: Право, 2010. - 240 с.

3. Магновський I. Формування внутрішнього права в умовах інтеграційних правових процесів сучасност / I. Магновський // Право України. - 2005. - № 3. - С. 118-121.

4. Галушко С. Сутність інноваційних технологій навчання та їх роль в активізації пізнавальної діяльності студентів / С. Галушко, 
Г. Гордашевська, Л. Галушко // Проблеми підготовки сучасного вчителя. - 2014. - № 9 (2). - С. 88-94.

5. Бистрова Ю. В. Інноваційні методи навчання у вищій школі України / Ю. В. Бистрова // Право та інноваційне суспільство. - 2015. № 1. - С. 27-33.

6. Леонтьєва В. М. Культуротворчість: природа, системи, процеси : автореф. дис. ... д. філос. наук : спец. 09.00 .04 / В. М. Леонтьєва. Харків, 2004. - 32 с.

7. Сидоренко Н. В. Інноваційна культура як вищий прояв загальнокультурних професійних та особистісних якостей учителя / Н. В. Сидоренко // Педагогічні науки: теорія, історія, інноваційні технології. - 2014. - № 3. - С. 337-346.

DOI https://doi.org/10.30525/978-9934-26-040-7-48

\section{ОСНОВНІ ПРИЧИНИ ПОШИРЕННЯ КОРУПЦІЇ В УКРАЇНІ}

Яфонкіна І. П.

кандидат політичних наук, викладач

Ірпінського державного коледжу економіки та права

м. Ірпінь, Київська область, Украӥна

\section{Яфонкін А. О.}

кандидат юридичних наук, дочент, доиент кафедри військової підготовки Університету державної фіскальної служби Украӥни м. Ірпінь, Київська область, Украӥна

\section{Шевчук В. А.}

кандидат юридичних наук, дочент, завідувач кафедри військової підготовки Університету держсавної фіскальної служби України м. Ірпінь, Київська область, Украӥна

Слід зазначити, що в Україні немає жодної сфери суспільного життя, де рівень корупції не досяг би тотальних масштабів. 